\title{
Article \\ Simulation Model of PV Module Built from Point-Focusing Fresnel Radiation Concentrators and Three-Junction High-Performance Cells
}

\author{
Mariusz T. Sarniak (D)
}

Citation: Sarniak, M.T. Simulation Model of PV Module Built from Point-Focusing Fresnel Radiation Concentrators and Three-Junction High-Performance Cells. Appl. Sci. 2022, 12, 806. https://doi.org/ 10.3390/app12020806

Academic Editor: Alireza

Dehghanisanij

Received: 2 January 2022

Accepted: 12 January 2022

Published: 13 January 2022

Publisher's Note: MDPI stays neutral with regard to jurisdictional claims in published maps and institutional affiliations.

Copyright: (C) 2022 by the author. Licensee MDPI, Basel, Switzerland. This article is an open access article distributed under the terms and conditions of the Creative Commons Attribution (CC BY) license (https:// creativecommons.org/licenses/by/ $4.0 /)$.
Faculty of Civil Engineering, Mechanics and Petrochemistry, Warsaw University of Technology, 09-400 Płock, Poland; mariusz.sarniak@pw.edu.pl

Featured Application: The model developed in this work has practical applications for simulating the operation of non-standard multi-junction photovoltaic modules with radiation concentrators.

\begin{abstract}
The silicon photovoltaic modules that dominate the market today are constantly being modified, but at the same time, the search for new, more efficient design solutions is underway. The study examined a less popular photovoltaic module built from point-focusing Fresnel radiation concentrators and high-efficiency three-junction cells. The advantage of this type of module is its high overall efficiency, exceeding $30 \%$. The disadvantage is that they require biaxial precision tracking mechanisms because even a small deviation of the direction of direct solar radiation from the perpendicular to the module's surface causes a large and abrupt drop in efficiency. This type of photovoltaic module structure is often also marked with the symbol C3PV. A mathematical model and simulation calculations were carried out in the Matlab/Simulink package for the C3PV module-the CX-75/200 model based on the "Solar Cell" component. The concentration of direct solar radiation was taken into account. For the module under consideration, experimental and simulation results show the necessity of accurate positioning concerning the direction of solar radiation-deviation of the radiation angle by about $5^{\circ}$ causes a very high power loss (by about $92 \%$ ).
\end{abstract}

Keywords: photovoltaics; mathematical model; photovoltaic module; Matlab; Simulink; solar cell; Fresnel lens

\section{Introduction}

Standard silicon PV modules, which directly convert solar energy into electricity, continue to dominate the market, and this dominance is estimated to last for another 15 years or so [1-4]. Recently, solar energy conversion technology has included intensively developed concentrated photovoltaic (CPV) technology, which converts solar energy into electricity radiation. Concentrated solar technologies use multilayer photovoltaic cells, which make the efficiency of converting solar energy into electricity about 2.5 times higher than that of conventional single-junction photovoltaic cells [5-9].

The subject of this paper is another less common photovoltaic module constructed from point-focused Fresnel radiation concentrators (CPVs) and high-efficiency three-junction (3J) cells. This type of photovoltaic module design is also often denoted by the symbol C3PV. The internal structure of this module is different from the standard one, and in this particular case for the model designated with the symbol CX-75/200, it consists of 200 three-junction cells, which are connected in four parallel connected series made of 50 cells each (50s4p). Each cell has a point-focusing Fresnel concentrator. The size ratio of the concentrator lens to the cell is $40 / 3 \mathrm{~mm}$, and the distance between them is $80 \mathrm{~mm}$. According to the CPV classification of concentric photovoltaic cells due to the degree of focusing on solar radiation, point-focusing Fresnel concentrators are classified as high concentrator photovoltaic (HCPV). Table 1 gives the generally accepted classification of 
photovoltaic systems using concentrators (CPV), which is a division based on the degree of focusing of the radiation measured in multiples, the so-called "suns", or in $\mathrm{W} / \mathrm{cm}^{2}$ of the cell $[10,11]$.

Table 1. Classification of concentric PV cells based on the degree of focusing of solar radiation, compiled based on [12].

\begin{tabular}{|c|c|c|c|}
\hline Name & $\begin{array}{c}\text { Focusing } \\
\text { Degree, } \\
\text { [Suns] }\end{array}$ & Type of Converter & $\begin{array}{c}\text { Type of } \\
\text { Recommended } \\
\text { Tracking System }\end{array}$ \\
\hline $\begin{array}{l}\text { Low Concentrator } \\
\text { Photovoltaic (LCPV) }\end{array}$ & $1.5-10$ & modified crystalline cells & none or single-axis \\
\hline $\begin{array}{l}\text { Medium Concentrator } \\
\text { Photovoltaic (MCPV) }\end{array}$ & $10-300$ & crystalline or thin-film cells & $\begin{array}{l}\text { single-axis or } \\
\text { dual-axis }\end{array}$ \\
\hline $\begin{array}{l}\text { High Concentrator } \\
\text { Photovoltaic (HCPV) }\end{array}$ & $300-2000$ & multijunction cells & dual-axis \\
\hline
\end{tabular}

In-service testing of this type of PV system has shown a very significant dependence of performance on the direction of direct solar radiation and the level of lens contamination [13].

Fresnel concentrators take the form of individual lens blocks that focus sunlight from each side of their upper surface toward a single point at which a photovoltaic cell is located. In a single point-focusing Fresnel concentrator in the shape of a square $(40 \mathrm{~mm})$, rings are formed on the surface, which makes use of the whole surface of the lens and results in a high concentration factor, which translates into higher efficiencies achieved by the cell. The advantage of this type of module is the high total efficiency exceeding $30 \%$. The disadvantage is that they require the use of biaxial precision tracking mechanisms because even a small deviation of the direction of direct solar radiation from the direction perpendicular to the surface of the module causes a large and abrupt drop in efficiency. The structure of the internal design of three-junction cells means that the focused incident radiation is captured by three cascaded layers of different materials, and overall, radiation from a wide range of wavelengths (300-1800 $\mathrm{nm}$ (for silicon, this range is 350-1100 nm)) is used. The different materials of the three-junction cell are stacked in such a way that each material absorbs a specific range of sunlight and, in a simplified way, this type of C3PV cell can be considered to absorb approx. $44 \%$ of photons are from sunlight, while an ordinary PV cell can do the same with an efficiency of about $20 \%$. The order is also important here-the outer layer must absorb the radiation with the smallest wavelength, that is, with the largest energy gap value of the semiconductor material. The materials used in the construction of the cells of the module under consideration are GaInP-GaInAs$\mathrm{aGe}$ in order from the top outer layer. Two conditions determine the higher efficiency of C3PV modules: the concentration of solar radiation and the fact that the photovoltaic phenomenon is realized in parallel by three junctions with different spectral ranges $[14,15]$.

In the scope of this work, a mathematical model was performed in the Matlab/Simulink package of the discussed C3PV module based on the "Solar Cell" component. The concentration of direct solar radiation was also considered in this model. Due to the lack of knowledge of the exact geometry of the Fresnel lenses used, test measurements were taken, in which the limit angle of deviation of the direction of direct radiation from the direction perpendicular to the module, effective focusing of the radiation, was determined to be about $5^{\circ}$. Once this value is exceeded, it was assumed that radiation focusing does not occur and only partially scattered radiation reaches the cell. Based on the built model, sample simulation calculations were performed in the form of current-voltage characteristics of the C3PV module for different angles of incidence of direct radiation on the module surface.

An analysis of the performance of two $3.5 \mathrm{~kW}_{\mathrm{p}}$ CPV systems for different types of Fresnel lenses under actual operating conditions showed that a dirty lens causes a drop in performance of up to about $12 \%$ with a level of module alignment inaccuracy of less 
than 1\% [13]. Other studies have also shown that the impact of tracking inaccuracy on the power output of CPV modules is very significant. It has been shown that CPV needs a solar tracking accuracy of at least $0.5^{\circ}$ to outperform other PV technologies [16]. The search for new solutions for CPV modules is also underway. A lens has been designed that is a combination of two linear Fresnel lenses placed perpendicular to each other and can collect and distribute direct sunlight in two dimensions. The simulation results show that the newly designed lens can achieve a high concentration ratio of 576 times [17]. The recent development of four-junction concentrator solar cells with record efficiency offers new opportunities to improve highly concentrated photovoltaic (HCPV) technology [18].

Investigations using an analytical GaInP/GaInAs/Ge three-junction solar cell model based on continuity and Poisson equations showed high agreement for an estimated efficiency of about 35\% [19,20].

\section{Materials and Methods}

\subsection{Construction of the C3PV Module under Test}

The appearance and internal connection structure of 200 three-junction (3J) cells are shown in Figure 1. This is a specific arrangement in which the cells are divided into four parallel connected rows of 50 cells each, and none of the connections intersect. A C3PV module with this design was chosen as an example for the developed simulation method and its initial verification.
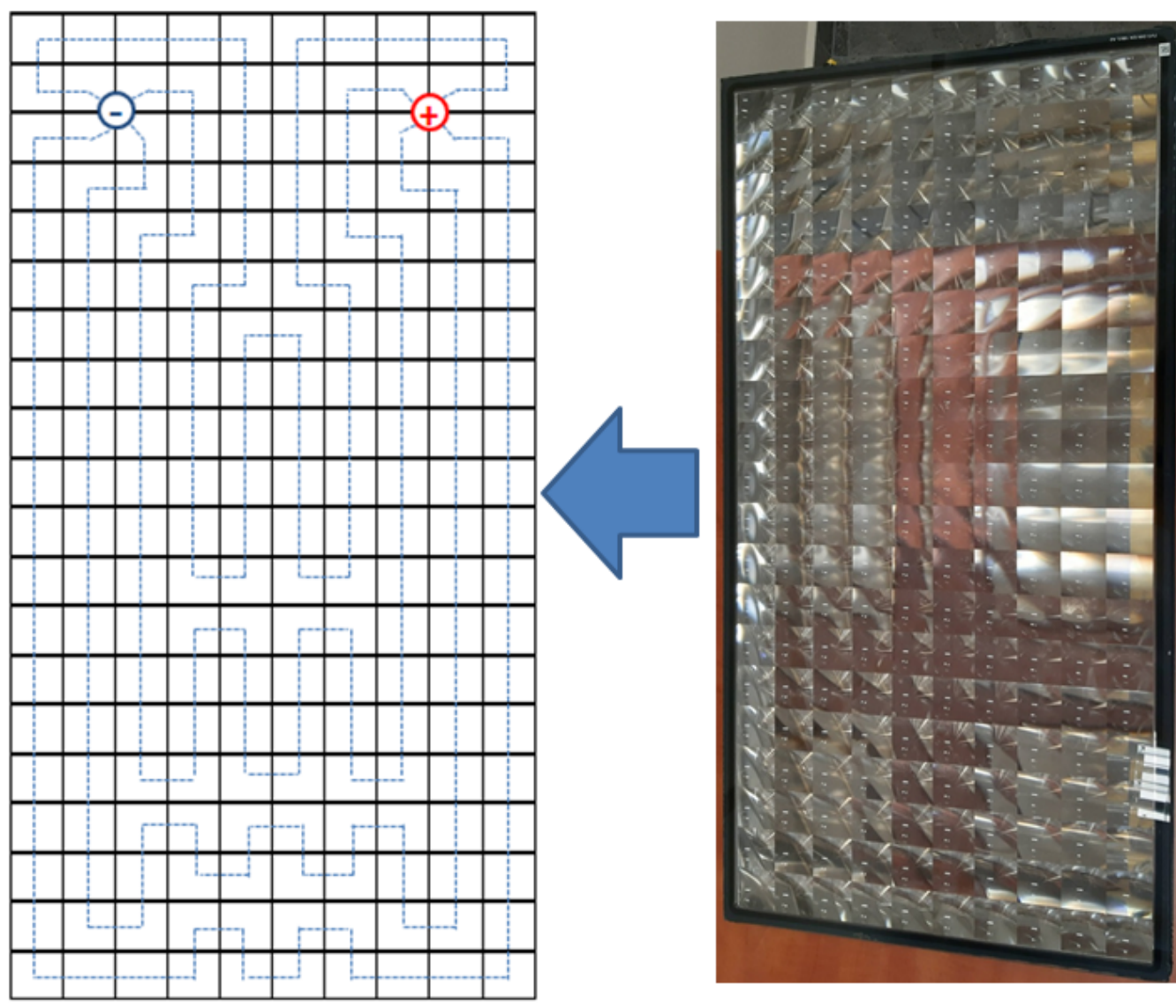

Figure 1. Appearance and design of internal cell connections in CX-75/200 module.

Table 2 shows the basic parameters of the tested C3PV module as given by the manufacturer. These parameters are given under non-standard test conditions, called standard test conditions (STCs). According to the manufacturer, the rated parameters given in the datasheet and nameplate were tested for solar irradiance $850 \mathrm{~W} / \mathrm{m}^{2}$, cell temperature $25{ }^{\circ} \mathrm{C}$, and AM 1.5. 
Table 2. Nominal parameters of CX-75/200 module [21].

\begin{tabular}{cc}
\hline Parameter Name & Module C3PV: CX-75/200 \\
\hline Cell type & three-junction \\
Number of cells, pcs. & 200 \\
Cell size $d, \mathrm{~mm}$ & 3 \\
Concentrator type & Fresnel spot-focusing \\
Maximum power $P_{M P P}, \mathrm{~W}$ & $75 \pm 10 \%$ \\
Open-circuit voltage $U_{O C}, \mathrm{~V}$ & 152 \\
Voltage to MPP $U_{M P P}, \mathrm{~V}$ & 138 \\
Short-circuit current $I_{S C}, \mathrm{~A}$ & 0.58 \\
Current for MPP $I_{M P P}, \mathrm{~A}$ & 0.54 \\
Temperature coefficient, $\% /{ }^{\circ} \mathrm{C}$ & -0.15 \\
temperature, ${ }^{\circ} \mathrm{C}$ & 55 \\
Maximum aperating temperature above ambient & 1000 \\
Maximum system operating voltage $U_{M A X}, \mathrm{~V}$ & $828 \times 428 \times 82$ \\
Dimensions, $\mathrm{mm}$ & 9.4 \\
Mass, $\mathrm{kg}$ &
\end{tabular}

Figure 2 presents a model of the structure of a single three-junction cell, which considers the ranges of absorbed radiation for three successive layers of semiconductors. Figure 2 gives the values of $E_{g}$ energy gaps for each layer and the percentage of absorbed energy reaching the cell in the form of concentrated solar radiation. The operating principle of this type of cell is that the size of the energy gap $\left(E_{g}\right)$ decreases in the direction consistent with the penetration of radiation. The purpose of building such structures is to absorb the broadest possible spectrum of solar radiation reaching the outer surface of the module.
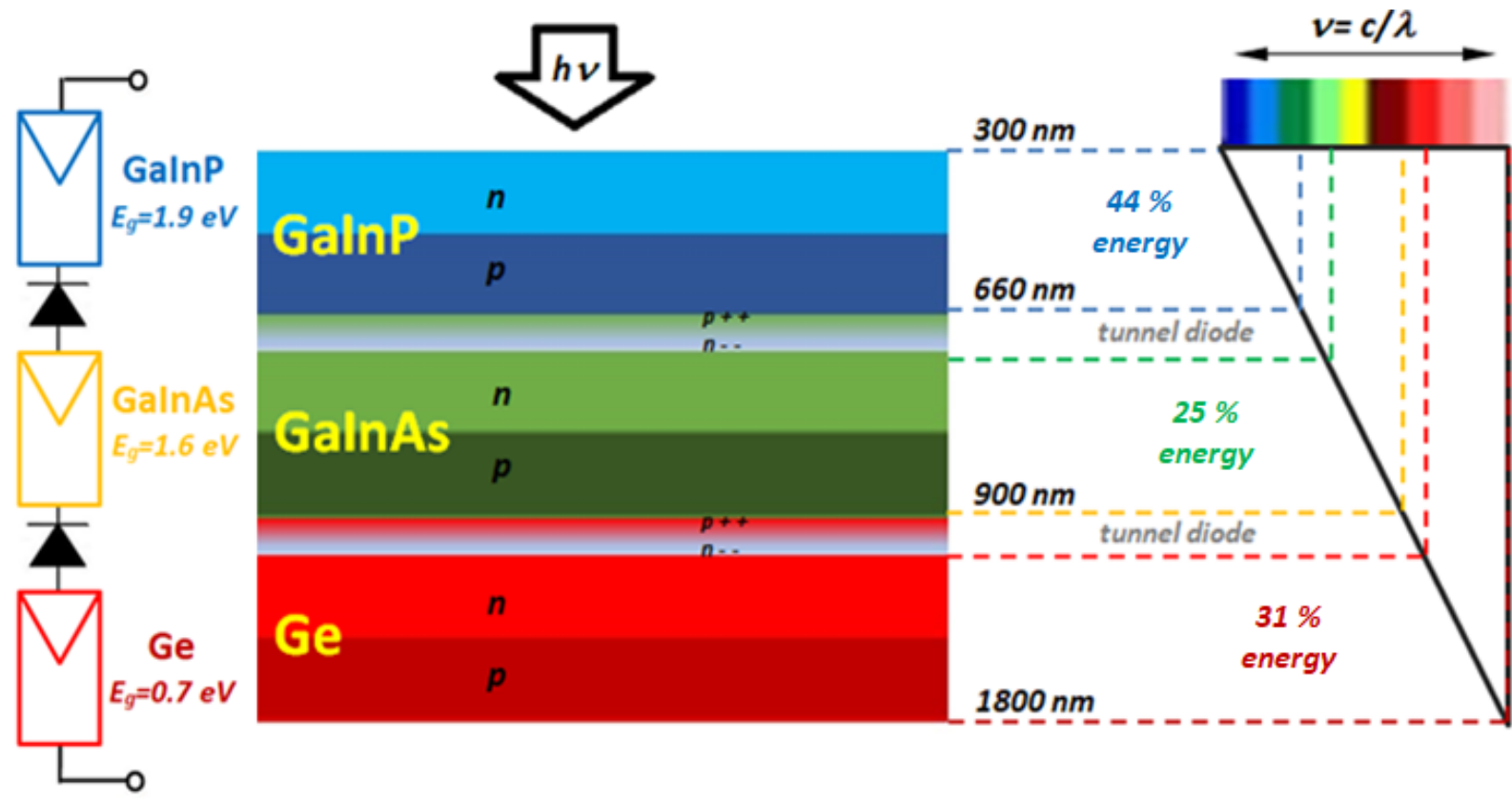

Figure 2. Structure and equivalent model of a single $3 \mathrm{~J}$ cell and the ranges of absorbed radiation.

The type of PV cell (3J) is designed to capture the maximum possible sunlight (300-1800 nm) as opposed to standard PV cells (only 350-1100 nm). The standard spectrum of solar radiation, which can theoretically be described by-laws (Planck, Stefan-Boltzmann, and Wien), is never fully utilized by photovoltaic cells. Multilayer modules broaden the absorbed spectrum, and the concentration of radiation multiplies this effect. The spectral ranges of solar radiation absorbed by individual layers of the cell under consideration are marked in Figure 2. The different materials in a three-junction cell are arranged so that each 
material absorbs a specific range of sunlight. C3PV cells absorb approx. $44 \%$ of photons from sunlight, while a regular PV cell can do the same with 15-20\% efficiency.

Figure 3 shows the radiation distribution patterns for an incident angle of radiation deviated from the perpendicular to the surface of a classical PV module (Figure 3a) and the operating principle of a point-focused Fresnel concentrator (Figure 3b). The diagram shown in Figure $3 b$ indicates the limited range of angle $( \pm \Delta \theta)$ of incidence of radiation that can fall in the C3PV cell area. A larger deviation of the incident angle causes the radiation to fall outside the C3PV cell area.

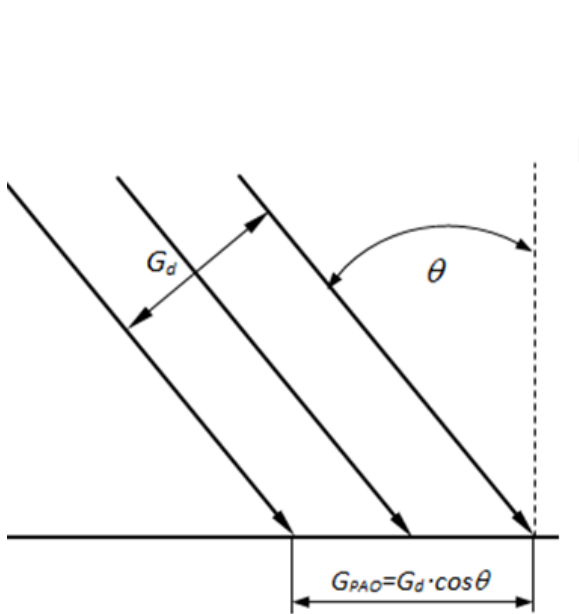

a)

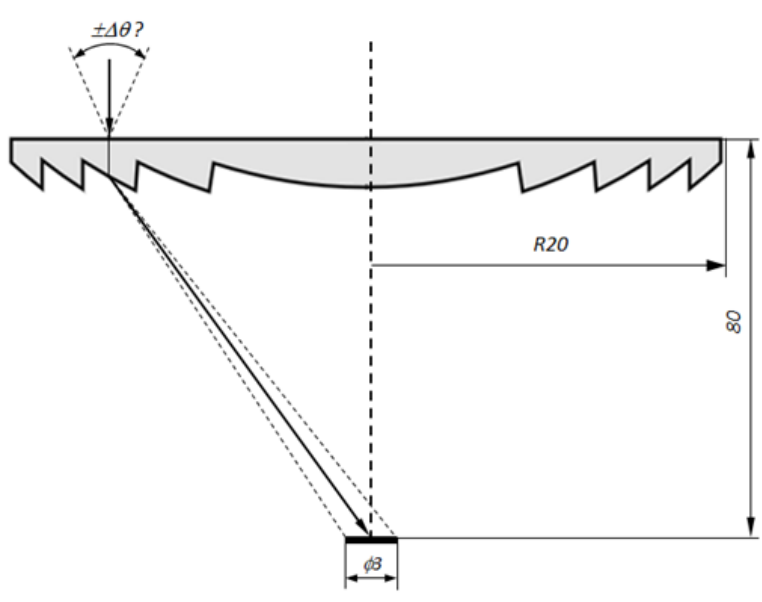

b)

Figure 3. Models of directional deflection of incident radiation on the cell surface: (a) for a classical PV module (plane of array (PAO)), (b) for a CPV module with a point-focus Fresnel concentrator.

\subsection{Building the Simulation Model}

Figure 4 shows the simulation model developed in a Matlab/Simulink package, reflecting the construction of the C3PV module discussed in this paper. The "Solar Cell" [22] component was used to build the model, in which a three-junction cell was implemented according to the scheme shown in Figure 2. The model also considers the deviation from the direction of incident direct radiation perpendicular to the module surface. A switch was used that implements the focusing algorithm through a Fresnel lens. It was experimentally determined that an angular deviation of $5^{\circ}$ from the perfectly perpendicular direction results in a sharp decrease in the module power. Thus, based on the schematic in Figure $3 b$, it can be hypothesized that a larger deviation causes focusing of the radiation outside the region of the triple-junction cell with $3 \mathrm{~mm}$ dimensions. The simulation model considers the semiconductor material parameters and absorbed radiation ranges, as shown in Figure 2. The simulation results are presented and recorded in current-voltage characteristic plots and power plots.

The novelty of the proposed model is that a standard module of the Matlab/Simulink package "Solar Cell" was used to build a three-junction cell model (C3PV). The model is relatively simple and allows other researchers to continue verification studies for similar custom solutions. The "Solar Cell" component was developed based on the classical model of a dual diode PV cell. Adapting the proposed model for other multijunction cells requires the determination of the range of the angle of deviation from the direction of perpendicular incident radiation and the degree of focusing. If the module manufacturer provides these data, they can be directly implemented in the model.

The basis for constructing the single three-junction cell model shown in Figure 4 is the series connection of three "Solar Cell" components, representing three successive layers of material as described in Figure 2. The structure of the C3PV module was modeled according to the module construction diagram shown in Figure 1. The structure of the modeled C3PV module was realized using a "Solar Cell" component, but in such an 
unusual way that three components replace a single cell. The connections between the three materials were modeled with tunnel diodes inserted in series in the equivalent circuit. As a simplifying assumption, the radiation flux distribution was taken as given for each layer of semiconductor material. The part of the model describing the optics of the concentrator was made using standard blocks of the Simulink package.

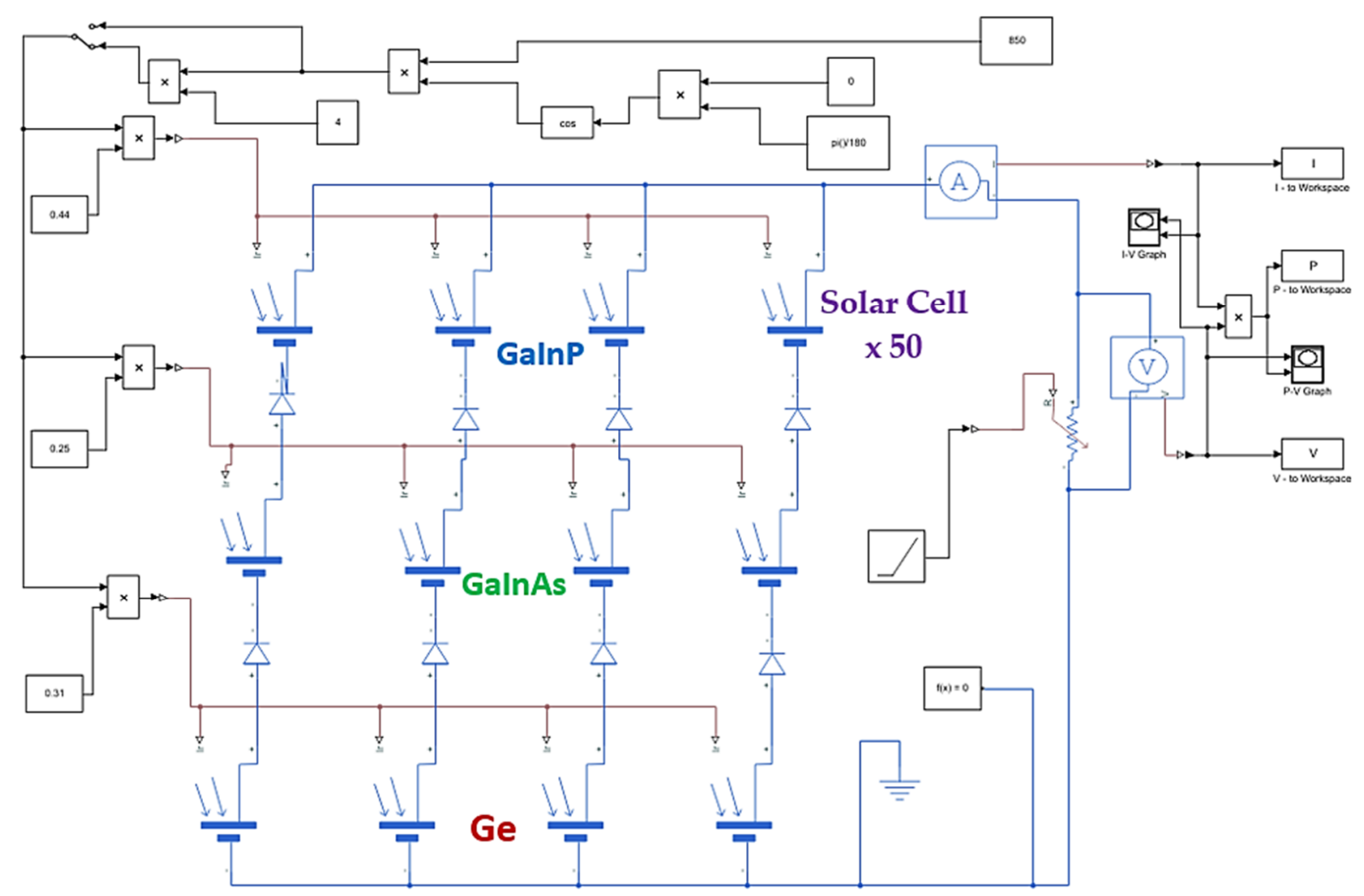

Figure 4. The simulation model of the C3PV module in Matlab/Simulink.

The "Solar Cell" component of the Matlab/Simulink engineering computing package is an equivalent model of a dual diode PV cell, the developed form of which is shown in Formulas (1) and (2). The mathematical form of this model is non-linear and entangled and can only be solved by iterative simulation calculations [23].

$$
\begin{gathered}
I=I_{p h}-I_{d 1}-I_{d 2}-I_{s h} \\
I=I_{p h}-I_{s 1}\left[\exp \left(q \frac{U+I R_{s}}{n_{1} k_{B} T_{M}}\right)-1\right]-I_{s 2}\left[\exp \left(q \frac{U+I R_{s}}{n_{2} k_{B} T_{M}}\right)-1\right]-\frac{U+I R_{s}}{R_{s h}}
\end{gathered}
$$

where $I, I_{p h}, I_{d 1}, I_{d 2}, I_{p h}$ mean, respectively, currents of the cell, photocurrent, diodes, and shunt; $U$-cell voltage; $R_{S}$ and $R_{s h}$-series and shunt resistances; $n_{1}$ and $n_{2}$-quality factors of the first and second diode; $I_{s 1}$ and $I_{s 2}$-saturation currents of the first and second diode; $T_{M}$-cell temperature; $q$ and $k_{B}$-electron charge and Boltzmann constant.

In the two-diode PV cell model, the diode current component has been divided into diffusion $\left(I_{d 1}\right)$ and recombination $\left(I_{d 2}\right)$ parts of the so-called dark diode current compared to the simplified model built on the basis of the single-diode scheme [24].

\section{Results}

The simulation model proposed in this paper was subjected to preliminary verification. The comparative material was the nominal parameters of the CX-75/200 module, given in Table 2, which were tested under the conditions given by the manufacturer $\left(850 \mathrm{~W} / \mathrm{m}^{2}\right.$, cell 
temperature $25^{\circ} \mathrm{C}$, and AM 1.5). The simulation results obtained for the nominal parameter values are shown in Figure 5.

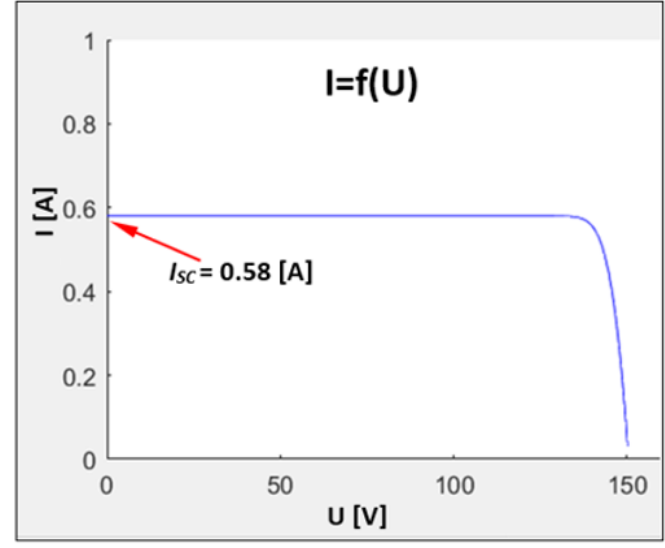

(a)

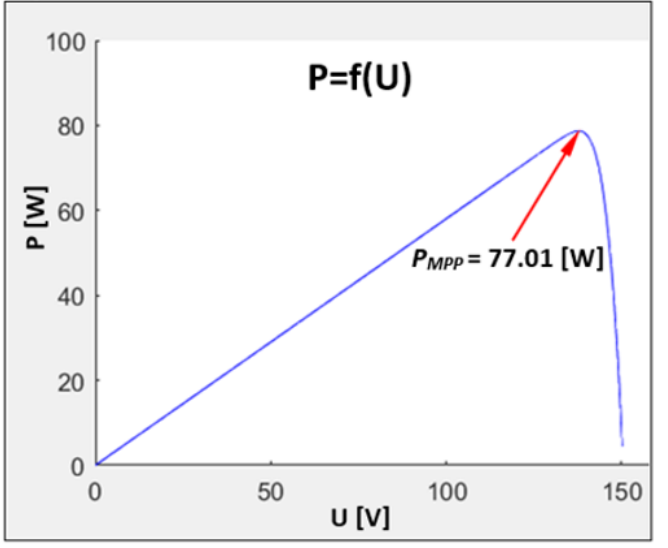

(b)

Figure 5. Simulation results for nominal parameters of CX-75/200 module: (a) current-voltage characteristic curve $\mathrm{I}=\mathrm{f}(\mathrm{U})$; $(\mathbf{b})$ power diagram $\mathrm{P}=\mathrm{f}(\mathrm{U})$.

After the positive initial verification of the proposed model shown in Figure 5, simulation studies were conducted, the results of which are presented in Figures 6-10. The simulation studies determined the essential characteristics for the modeled C3PV CX$75 / 200$ module at a constant irradiance level of $300 \mathrm{~W} / \mathrm{m}^{2}$ and a variable angle of incidence of direct radiation in the range of $0-10^{\circ}$. The irradiance $\left(300 \mathrm{~W} / \mathrm{m}^{2}\right)$ was assumed to be the same as in the experimental determination of the applicability range of the model, when a value of $5^{\circ}$ angle was set as the limit after which the power generated by the cell dropped significantly. The irradiance was obtained using a solar radiation simulator built with halogen lamps [25].

Complete verification of the developed simulation method by measuring actual I-V characteristics for the CX-75/200 module is not possible due to measurement limitations of the meters. An attempt to use the I-V $400 \mathrm{w}$ [26] current-voltage characteristic meter for this purpose was unsuccessful because this meter and others like it cannot take measurements at such low current values of the PV module.

The simulation results shown in Figure 6 for irradiance of $300 \mathrm{~W} / \mathrm{m}^{2}$ and a module temperature of $21^{\circ} \mathrm{C}$ showed a proportional decrease in value for the short-circuit current in the I-V characteristic curve.

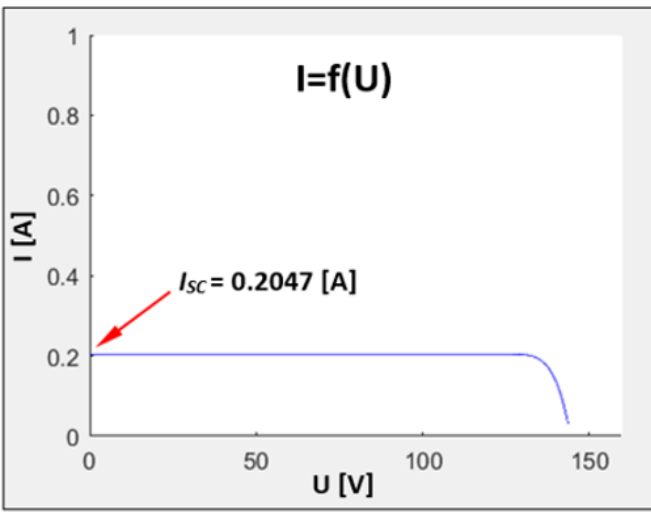

(a)

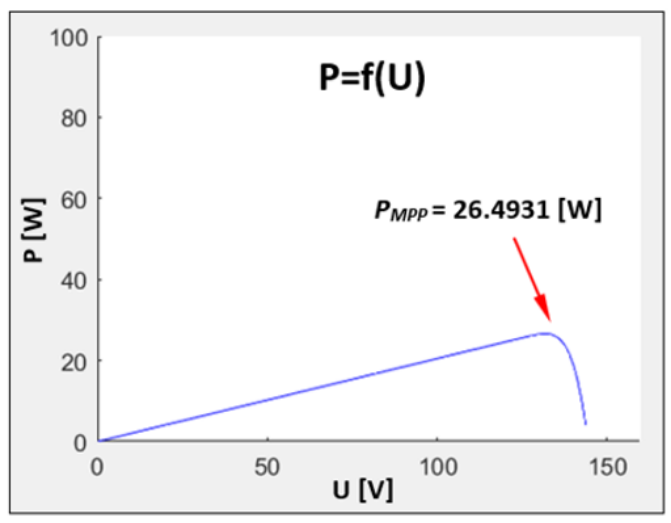

(b)

Figure 6. Simulation results for irradiance $300 \mathrm{~W} / \mathrm{m}^{2}$ and temperature $21^{\circ} \mathrm{C}$ for modeled CX-75/200 module: (a) current-voltage characteristic curve $\mathrm{I}=\mathrm{f}(\mathrm{U})$; (b) power diagram $\mathrm{P}=\mathrm{f}(\mathrm{U})$. 


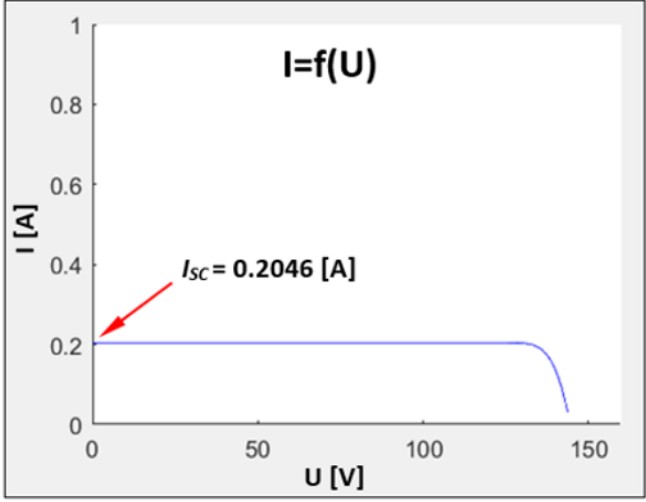

(a)

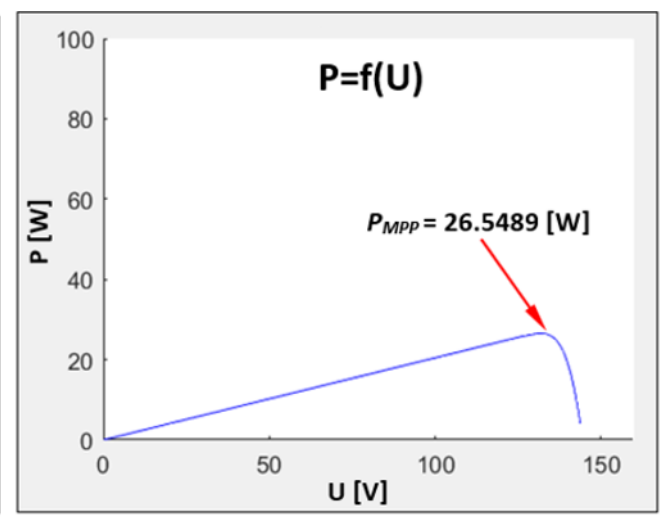

(b)

Figure 7. Simulation results for irradiance of $300 \mathrm{~W} / \mathrm{m}^{2}$ deflected by an angle $\Delta \theta=2^{\circ}$ from the direction of perpendicular incidence and a temperature of $21^{\circ} \mathrm{C}$ for the modeled CX-75/200 module: (a) current-voltage characteristics $\mathrm{I}=\mathrm{f}(\mathrm{U})$; (b) power graph $\mathrm{P}=\mathrm{f}(\mathrm{U})$.

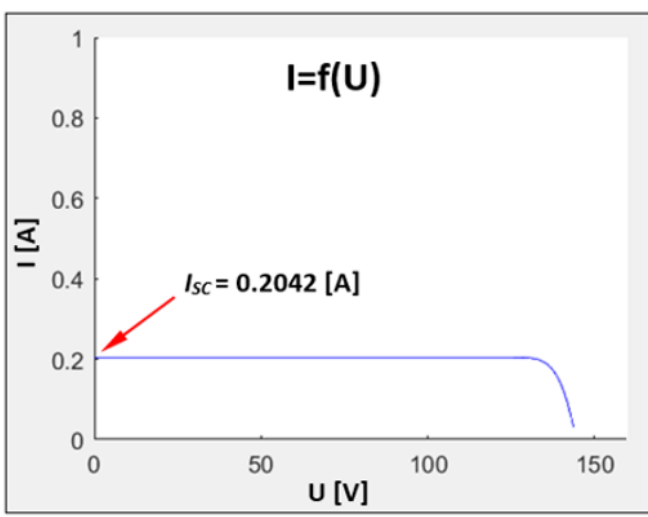

(a)

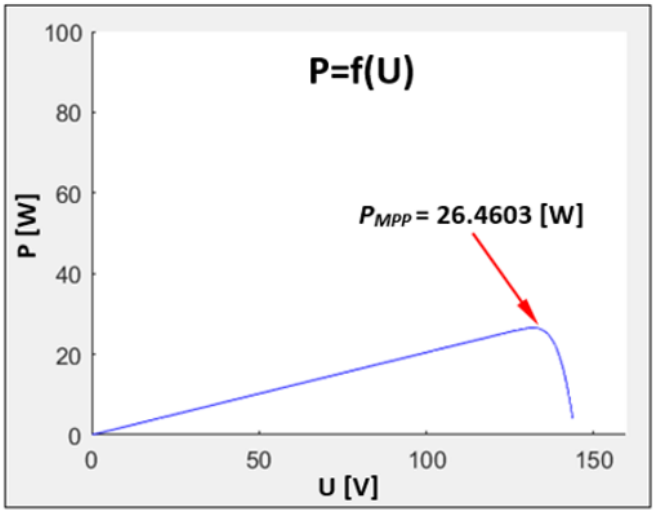

(b)

Figure 8. Simulation results for irradiance of $300 \mathrm{~W} / \mathrm{m}^{2}$ deflected by an angle $\Delta \theta=4^{\circ}$ from the direction of perpendicular incidence and a temperature of $21^{\circ} \mathrm{C}$ for the modeled CX-75/200 module: (a) current-voltage characteristics $I=f(U)$; (b) power graph $\mathrm{P}=\mathrm{f}(\mathrm{U})$.

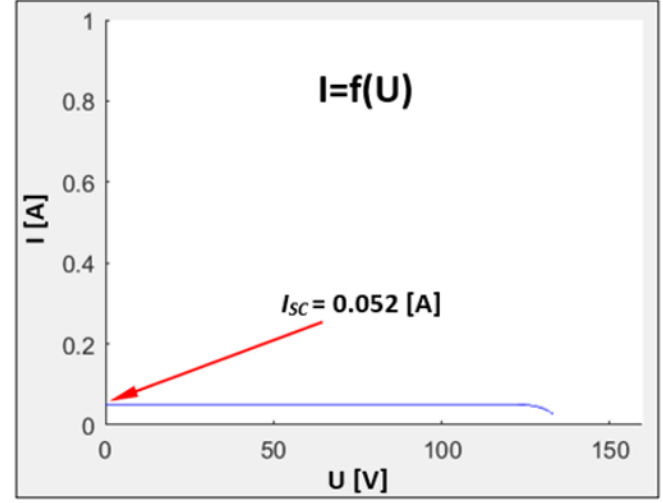

(a)

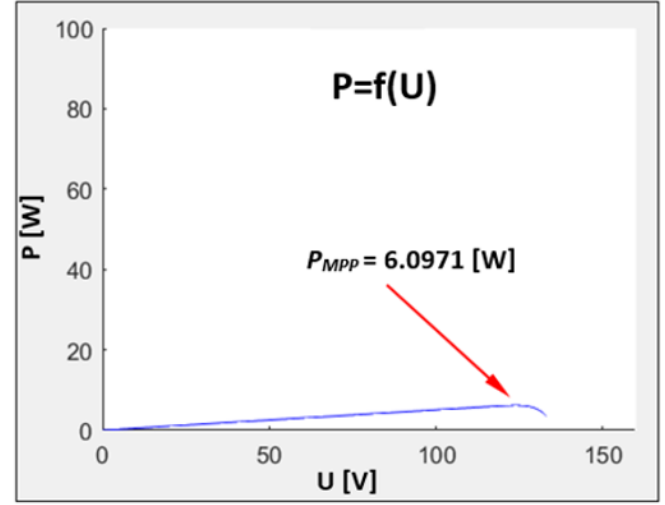

(b)

Figure 9. Simulation results for irradiance of $300 \mathrm{~W} / \mathrm{m}^{2}$ deflected by an angle $\Delta \theta=5^{\circ}$ from the direction of perpendicular incidence and a temperature of $21^{\circ} \mathrm{C}$ for the modeled $\mathrm{CX}-75 / 200$ module: (a) current-voltage characteristics $\mathrm{I}=\mathrm{f}(\mathrm{U})$; (b) power graph $\mathrm{P}=\mathrm{f}(\mathrm{U})$. 


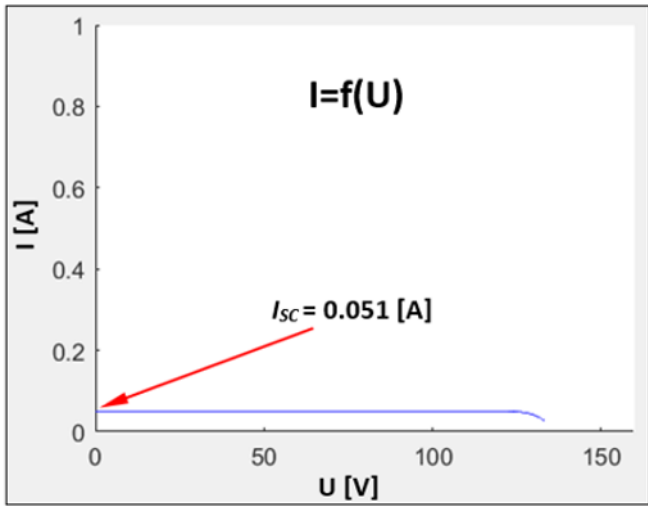

(a)

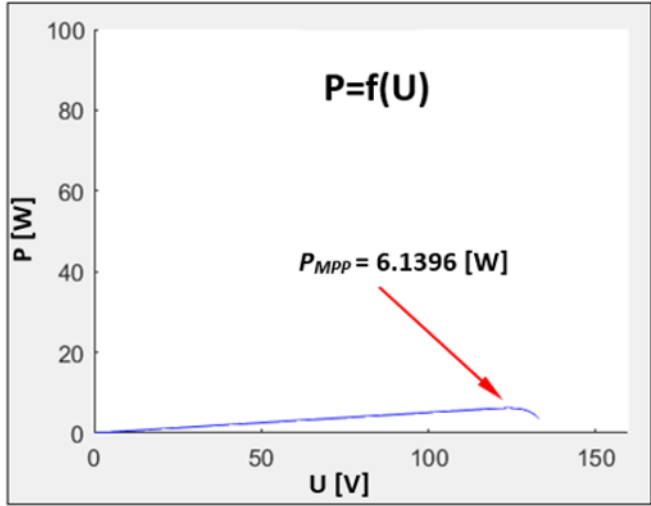

(b)

Figure 10. Simulation results for irradiance of $300 \mathrm{~W} / \mathrm{m}^{2}$ deflected by an angle $\Delta \theta=10^{\circ}$ from the direction of perpendicular incidence and a temperature of $21^{\circ} \mathrm{C}$ for the modeled $\mathrm{CX}-75 / 200$ module: (a) current-voltage characteristics $\mathrm{I}=\mathrm{f}(\mathrm{U})$; (b) power graph $\mathrm{P}=\mathrm{f}(\mathrm{U})$.

In the following Figures 7-10, for the same radiation and temperature conditions, the incident direction of the radiation measured by the deviation $(\Delta \theta-$ per Figure $3 b)$ from the perpendicular direction was changed. For angle deviations from $5^{\circ}$, a sharp decrease in short-circuit current values was observed.

Figures 9 and 10 clearly show that radiation concentration no longer works. A small amount of energy is generated from diffuse solar radiation.

Table 3 shows the numerical results of the current-voltage characteristics and power values for each bias angle used in this simulation for a fixed irradiance of $300 \mathrm{~W} / \mathrm{m}^{2}$ and an assumed module temperature of $21^{\circ} \mathrm{C}$. The given numerical values of these three current-voltage characteristic points allow comprehensive further considerations on the efficiency or fill factor of the considered module.

Table 3. Numerical results of current-voltage characteristics and power values for each deflection angle used in this simulation for a fixed irradiance of $300 \mathrm{~W} / \mathrm{m}^{2}$ and an assumed module temperature of $21^{\circ} \mathrm{C}$.

\begin{tabular}{|c|c|c|c|}
\hline $\begin{array}{l}\text { Deviation of the } \\
\text { Radiation Angle } \\
\qquad \Delta \theta,(\mathrm{deg})\end{array}$ & $\begin{array}{c}\text { Short-Circuit } \\
\text { Current } \\
I_{S C},(\mathrm{~A})\end{array}$ & $\begin{array}{c}\text { Open-Circuit } \\
\text { Voltage } \\
U_{O C},(\mathrm{~V})\end{array}$ & $\begin{array}{c}\text { Maximum Power } \\
\text { Point } \\
P_{M P P},(W)\end{array}$ \\
\hline 0 & 0.2047 & 129.424 & 26.4931 \\
\hline 2 & 0.2046 & 129.76 & 26.5489 \\
\hline 4 & 0.2042 & 129.5803 & 26.4603 \\
\hline 5 & 0.052 & 117.2519 & 6.0971 \\
\hline 10 & 0.051 & 120.3843 & 6.1396 \\
\hline
\end{tabular}

\section{Discussion and Conclusions}

The simulation results obtained are the basis for the construction of effective control algorithms of dual-axis tracking systems. Research has shown that much higher positioning accuracy is required for CPV-type modules than for standard silicon modules. Control algorithms for these types of PV modules require frequent checks on the position of the Sun's apparent movement in the sky. For the module under consideration, a deviation of the incidence angle from perpendicular above $5^{\circ}$ causes a drastic decrease in the module power (by about 92\%). The results showed less sensitivity to the deviation of the radiation direction than in some other studies [13]. The detailed adaptation of the proposed model of multilayer concentric PV cells requires very precise knowledge of the geometry of the focusing radiation element. Unfortunately, the data sheets of this type of PV modules do not always provide these technical details and the task is then made difficult as in the case considered in this work. 
The studies, which attempted to solve this problem in an analytical way [27], led to positive verification of the adopted models. The problem that should be addressed in the future is the issue of economic viability of this type of solutions. Comparative analyses for evaluating the impact of the radiation spectrum on the energy yield of highly concentrated and conventional photovoltaic technology are based on the air mass (AM) factor in many studies [28].

The model proposed in this paper can be easily modified for other non-standard solutions, such as cells with more layers of semiconductor material. It is also possible to modify the module that calculates the geometric parameters of the direct solar radiation direction. The proposed model can also be modified to use other solar beam focusing mechanisms. The photovoltaic market in Central Europe, based on the example of Poland [29], has to be more and more competitive and look for more and more efficient technical solutions. The model proposed in this paper can also be adapted in the future to the latest solutions, consisting in combining classical silicon with new materials such as perovskites. Another new challenge for modeling such systems will be to predict the durability of such cells. For classical silicon PV modules, an average annual power loss of about $0.8 \%$ is currently assumed [30].

This paper demonstrates that different PV cell structures operate on similar solar radiation conversion mechanisms. After appropriate adaptation, proven and tested engineering software components such as "Solar Cell" of the Matlab/Simulink package can be used to conduct simulation experiments of cells with various unusual structures. In classical applications in earlier work [31-33], the author has positively verified the usefulness of the "Solar Cell" component of the Matlab/Simulink engineering computing package.

Funding: This research received no external funding.

Institutional Review Board Statement: Not applicable.

Informed Consent Statement: Not applicable.

Data Availability Statement: Not applicable.

Conflicts of Interest: The author declares no conflict of interest.

\section{References}

1. Conibeer, G.; Willoughby, A. Solar Cell Materials: Developing Technologies, 1st ed.; John Wiley \& Sons: Hoboken, NJ, USA, 2014; ISBN 978-1-118-69581-4.

2. Messenger, R.A.; Ventre, A. Photovoltaic Systems Engineering, 4th ed.; CRC Press Taylor \& Francis Group: Boca Raton, FL, USA, USA, 2017; ISBN 978-1-4398-0293-9.

3. Kalogirou, S. McEvoy's Handbook of Photovoltaics, 3rd ed.; Elsevier: Amsterdam, The Netherlands, 2018; ISBN 9780128099216.

4. Sarniak, M.T. Photovoltaic Systems; Warsaw University of Technology Publishing House: Warsaw, Poland, 2021; ISBN 978-83-7814-926-2.

5. Zhang, H.L.; Baeyens, J.; Degrève, J.; Cacères, G. Concentrated solar power plants: Review and design methodology. Renew. Sustain. Energy Rev. 2013, 22, 466-481. [CrossRef]

6. Choubey, P.C.; Dewangan, A.; Oudhia, R. A review: Solar cell current scenario and future trends. Recent Res. Sci. Technol. 2012, 4 , 99-101.

7. GENI Review and Comparison of Different Solar Energy Technologies. Available online: http://citeseerx.ist.psu.edu/viewdoc/ download?doi=10.1.1.461.1641\&rep=rep1\&type=pdf (accessed on 22 November 2021).

8. Emery, K. Solar cell efficiency tables (version 47). Prog. Photovoltaics Res. Appl. 2015, 24, 3.

9. IRENA International Renewable Energy Agency. Available online: https://www.irena.org/ (accessed on 22 November 2021).

10. Fathabadi, H. Novel high efficient offline sensorless dual-axis solar tracker for using in photovoltaic systems and solar concentrators. Renew. Energy 2016, 95, 485-494. [CrossRef]

11. Carpanelli, M.; Borelli, G.; Verdilio, D.; De Nardis, D.; Migali, F.; Cancro, C.; Graditi, G. Characterization of the Ecosole HCPV tracker and single module inverter. AIP Conf. Proc. 2015, 1679, 120001. [CrossRef]

12. Mroziński, A. Inżynieria Instalacji Fotowoltaicznych; Grafpol: Bydgoszcz, Poland, 2016; ISBN 9788364423406.

13. Renzi, M.; Egidi, L.; Comodi, G. Performance analysis of two $3.5 \mathrm{kWp} \mathrm{CPV} \mathrm{systems} \mathrm{under} \mathrm{real} \mathrm{operating} \mathrm{conditions.} \mathrm{Appl.} \mathrm{Energy}$ 2015, 160, 687-696. [CrossRef]

14. ENCON Solar Pvt. Ltd. Solar Technologies. Available online: http://www.enconre.com/technology.html (accessed on 17 November 2021). 
15. Kurtz, S.; Geisz, J. Multijunction solar cells for conversion of concentrated sunlight to electricity. Opt. Express 2010, 18, A73. [CrossRef]

16. Zsiborács, H.; Baranyai, N.; Vincze, A.; Weihs, P.; Schreier, S.; Gützer, C.; Revesz, M.; Pintér, G. The Impacts of Tracking System Inaccuracy on CPV Module Power. Processes 2020, 8, 1278. [CrossRef]

17. Pham, T.; Vu, N.; Shin, S. Novel Design of Primary Optical Elements Based on a Linear Fresnel Lens for Concentrator Photovoltaic Technology. Energies 2019, 12, 1209. [CrossRef]

18. Ferrer-Rodríguez, J.; Valera, A.; Fernández, E.; Almonacid, F.; Pérez-Higueras, P. Ray Tracing Comparison between Triple-Junction and Four-Junction Solar Cells in PMMA Fresnel-Based High-CPV Units. Energies 2018, 11, 2455. [CrossRef]

19. Ataser, T.; Ozturk, M.K.; Zeybek, O.; Ozcelik, S. An Examination of the GaInP/GaInAs/Ge Triple Junction Solar Cell with the Analytical Solar Cell Model. Acta Phys. Pol. 2019, 136, 21-25. [CrossRef]

20. Fetzer, C.M.; King, R.R.; Colter, P.C.; Edmondson, K.M.; Law, D.C.; Stavrides, A.P.; Yoon, H.; Ermer, J.H.; Romero, M.J.; Karam, N.H. High-efficiency metamorphic GaInP/GaInAs/Ge solar cells grown by MOVPE. J. Cryst. Growth 2004, 261, 341-348. [CrossRef]

21. Marketplace SECONDSOL. Available online: https://www.secondsol.com/en/anzeige/12163/modules/cpv/concentrix-solar/ cX-75-ii (accessed on 17 November 2021).

22. Mathworks Solar Cell Block. Available online: https://www.mathworks.com/help/physmod/sps/ref/solarcell.html (accessed on 30 December 2021).

23. Drabczyk, K.; Panek, P. Silicon-Based Sollar Cells. Characteristics and Production Processes; Institute of Metallurgy and Materials Science of Polish Academy of Sciences: Krakow, Poland, 2012; ISBN 978-83-62098-07-1.

24. Sharma, C.; Jain, A. Solar Panel Mathematical Modeling Using Simulink. J. Eng. Res. Appl. 2014, 1, 67-72.

25. Sarniak, M.T. The Efficiency of Obtaining Electricity and Heat from the Photovoltaic Module under Different Irradiance Conditions. Energies 2021, 14, 8271. [CrossRef]

26. HT ITALIA Specifications Meter Characteristics I-V 400. Available online: https://www.ht-instruments.com/en/products/ photovoltaic-testers / i-v-curve-tracers/i-v400w / (accessed on 30 November 2021).

27. Theristis, M.; Fernández, E.; Almonacid, F.; Georghiou, G. Spectral Correction of CPV Modules Equipped with GaInP/GaInAs/Ge Solar Cells and Fresnel Lenses. Appl. Sci. 2017, 7, 842. [CrossRef]

28. Fernández, E.F.; Soria-Moya, A.; Almonacid, F.; Aguilera, J. Comparative assessment of the spectral impact on the energy yield of high concentrator and conventional photovoltaic technology. Sol. Energy Mater. Sol. Cells 2016, 147, 185-197. [CrossRef]

29. Duda, J.; Kusa, R.; Pietruszko, S.; Smol, M.; Suder, M.; Teneta, J.; Wójtowicz, T.; Żdanowicz, T. Development of Roadmap for Photovoltaic Solar Technologies and Market in Poland. Energies 2021, 15, 174. [CrossRef]

30. Żdanowicz, T. Photovoltaic system (PV) reception-procedures and documentation-part 2 (in Polish). Magazynfotowoltaika 2018, 1 , 16-20.

31. Sarniak, M.T.; Wernik, J.; Wołosz, K.J. Application of the Double Diode Model of Photovoltaic Cells for Simulation Studies on the Impact of Partial Shading of Silicon Photovoltaic Modules on the Waveforms of Their Current-Voltage Characteristic. Energies 2019, 12, 2421. [CrossRef]

32. Sarniak, M.T. Modeling the Functioning of the Half-Cells Photovoltaic Module under Partial Shading in the Matlab Package. Appl. Sci. 2020, 10, 2575. [CrossRef]

33. Sarniak, M. Modeling of photovoltaic modules in Simulink and Simscape packages of Matlab software. Econtechmod. Int. Q. J. 2017, 6, 133-138. 